\title{
POTENTIAL PHYTOCONSTITUENTS FROM NATURAL PRODUCTS FOR COMBATING AGAINST CORONAVIRUS DISEASE-19 (SEVERE ACUTE RESPIRATORY SYNDROME CORONAVIRUS-2) - A REVIEW
}

\author{
CHANDRASEKAR R ${ }^{1 *}$, SIVAGAMI ${ }^{2}$, SATHEESH KUMAR G \\ ${ }^{1}$ Department of Pharmacognosy, Seven Hills College of Pharmacy, Tirupati, Andhra Pradesh, India. ${ }^{2}$ Department of Pharmaceutical \\ Analysis, Seven Hills College of Pharmacy, Tirupati, Andhra Pradesh, India. ${ }^{3}$ Department of Pharmaceutical Chemistry, Seven Hills College \\ of Pharmacy, Tirupati, Andhra Pradesh, India. Email: chandrumnrcop@gmail.com
}

Received: 17 May 2021, Revised and Accepted: 14 September 2021

ABSTRACT

Coronavirus called as coronavirus diseases (COVID)-19 (severe acute respiratory syndrome coronavirus [SARS-CoV]-2) is a viral infection which is spreading to a great extent and affecting many people worldwide, many developed and developing countries are severely affected by the virus. The World Health Organization (WHO) is taking serious preventive measures to stop this viral infection worldwide. The coronavirus is a big threat to human beings and controlling the emerging viral infections is a global concern. Antiviral drug such as Remdesivir has been approved by the FDA, but combating against these viral infections is a great challenge to scientists and researchers with the available few antiviral drugs due to severe side effects and toxicity. Many drugs such as hydroxy chloroquin, Remdesivir, and vaccines have been recommended for combating this virus. Few Polyherbal formulations and Ayurvedic formulations containing antiviral phytoconstituents have been recommended to boost the immunity. Some drugs and phytoconstituents are under different phases of human clinical trials. The currently available synthetic drugs and vaccines for the treatment of viral infections have severe side effects. Medicinal plants play a critical role in treating viral infections by developing immunity against viral diseases. Some medicinal plants which were used as antipyretic, analgesic, and anti-inflammatory activity helped in treating various diseases and viral infections. Many plants contain flavonoids such as quercetin, luteolin, apigenin, and polyphenols such as thymoquinone, phytosteroids such as cucurbitacin and others which may likely to act as antioxidants and immunomodulatory that can fight against COVID-19. The current review provides information on phytochemical constituents present in medicinal plants, their mechanism of action, in silico molecular docking studies and human clinical trials to treat viral disorders.

Keywords: Anti-antiviral activity, Coronavirus diseases-19, in silico molecular docking, Natural products, Phytoconstituents, Anti-antiviral activity and coronavirus diseases-19, Drug candidates.

(c) 2021 The Authors. Published by Innovare Academic Sciences Pvt Ltd. This is an open access article under the CC BY license (http://creativecommons.org/ licenses/by/4.0// DOI: http://dx.doi.org/10.22159/ajpcr.2021v14i10.42399. Journal homepage: https://innovareacademics.in/journals/index.php/ajpcr

\section{INTRODUCTION}

Coronavirus called as coronavirus diseases (COVID)-19 pandemic a severe acute respiratory syndrome coronavirus 2 (SARS-CoV-2) is a viral infection which is spreading to a great extent and many people are affected with the virus worldwide. The WHO has taken various preventive measures and recommended countries and advised people to wear masks, use sanitizers, wash hands regularly, maintaining social distance and also advised to boost their immunity by taking nutritious food and Immunomodulators. Hence, many developed and developing countries are affected with this virus. Scientists and researchers around the globe are inventing new drugs and identifying new phytochemical compounds to fight against viral infections. Since viral diseases are spreading to a large extent worldwide, stopping the spreading of infections is a global concern. Since people nowadays do not have natural immunity, so increasing immunity is also a global concern [1]. Coronavirus a deadly virus killing many people in the world, this virus is an air borne virus which spreads in air either by coughing and sneezing and easily invades the lungs through nose or mouth. The virus invades the respiratory tract and creates difficulty in breathing. The virus takes a week and then invades the lower respiratory tract and slowly creates difficulty in breathing. The patient must be isolated for 2-3 weeks to avoid spreading of the virus to other people; it may take around 4 weeks for complete recovery from the viral infection [2]. People affected with Coronavirus can experience a mildto-moderate symptoms such as respiratory illness and recover without requiring hospitalization for treatment. However, this is not in the case with older people with chronic illness such as chronic respiratory illness, cardiovascular problem, diabetes, and cancer may experience serious symptoms. The symptoms for Coronavirus include fever, dry cough, tiredness, body pains, throat infection, diarrhea, conjunctivitis, headache, loss of taste or smell, skin rashes, and discoloration of fingers and toes. Difficulty in breathing, chest pain and loss of speech are the serious and severe symptoms. The virus can spread by coughing and sneezing, the spreading can be prevented by covering the nose and mouth [3]. Remdesivir is a prodrug a ribonucleotide analogue inhibitor of viral RNA polymerase. Remdesivir was approved by the FDA for the treatment of COVID-19 which has been recommended by the WHO. Remdesivir was developed for the treatment of hepatitis C, Ebola virus disease, and other viral infections. It has also been investigated for its in vitro activity against SARS-CoV-2. Remdesivir decreased the virus levels in the lungs and exhibited less lung damage in patients with COVID-19 [4].

\section{STRUCTURE AND FUNCTIONS OF LUNGS}

The lungs are present in the thoracic cavity, which is enclosed by the rib cage. The ribcage protects the lungs from injury. The diaphragm is a skeletal muscle sheet that runs from the base of the lungs to the top of the lungs. The diaphragm separates the stomach and intestines from the lungs. The diaphragm is controlled by the sympathetic nervous system, and its primary function is respiration. The upper and lower respiratory tracts make up the respiratory tract. The nose and nasal passages, as well as the pharynx and larynx, which are located above the vocal cords, make up the upper respiratory tract. The larynx, which is located below the vocal cords, as well as the trachea, bronchi, and bronchioles, make up the lower respiratory tract. The lungs, which are found in the lower respiratory tract, contain the respiratory bronchioles, 
alveolar ducts, alveolar sacs, and alveoli. The nasal cavity is where air initially enters the nose; the inner layer of the nose is made up of a layer of nasal mucosa that functions as a filter, preventing hazardous substances, and pollutants from entering. The air passes through the pharynx, which connects the esophagus and the larynx. The epiglottis is a unique layer of cartilage that covers the larynx. The epiglottis opens to allow air into the alveoli but shuts to keep food out of the airway. The air enters the larynx and travels to the trachea, where it splits into the right and left main bronchi. The bronchi are made up of smaller structures called bronchioles that eventually join with specialized microscopic structures. Each bronchi split into a secondary bronchus that rises into tertiary bronchi called alveoli; the main function of alveoli is gaseous exchange [5].

\section{STEAM THERAPY FOR COVID-19}

Steam therapy is a best alternative method to overcome the symptoms of COVID-19, steam therapy with volatile oil containing plants, cinnamon bark, Cinnamon zeylanicum, clove, Eugenia caryophyllus, garlic, Allium sativum, black pepper, Piper nigrum, Piper betle, ginger, Zingiber officinale, etc. Steam inhalation is the most extensively used homemade remedy in the nasal passages to get relief from respiratory infections such as common cold and sinus problems. In this method, water vapor from warm water passes into the mucus membrane into the nasal passages, throats, and lungs. The water vapor from steam can get rid of symptoms such as alleviate irritation in the mucous membrane, inflammation, swollen blood vessels, relaxation of throat muscles, soreness and inflammation and dilates blood vessels improving blood circulation congestion, and other respiratory symptoms. Steam therapy can be recommended for a blocked nose, inflammation in the blood vessels and acute upper respiratory infection such as a cold or sinus infection [6].

Many medicinal plants contain flavonoids such as quercetin, luteolin, apigenin, and polyphenols such as thymoquinone, phytosteroids such as cucurbitacin and others which may likely to act exhibiting antioxidant and immunomodulatory activity that can quell the cytokine storm in COVID-19. Virus replication is inhibited by zinc as zinc inhibits viral Rdrp enzyme. Zinc is to be taken into cell by zinc ionophore compounds such as quercetin (naturally present in red onion, guava leaves and fruit, blue berries, and grape seeds) and thymoquinone. As plants contain quercetin and thymoquinone, they take zinc into cell and inhibit viral Rdrp; hence, there is possibility of stopping viral replication of SARSCOV-2 virus. Cytokine storm can be stopped by either flavonoids such as quercetin or phytosterols present in plants.

\section{THE ROLE OF HERBAL MEDICINE}

The Indian system of medicine or alternative system of medicine which include Ayurveda, Siddha, Unani, and Homeopathy are effective against many diseases, including viral infections and cancer but potency, quality, and safety needs to be enhanced in certain stages of production. The associated adverse effects and side effects need to be reduced. A number of new herbal products are introduced in the global market every year. About $80 \%$ of the people in developed and developing countries in many parts of the world still rely on traditional herbal medicine and their products for their primary healthcare and living [7]. Phytoconstituents present in natural products have been used for the treatment of many chronic disease conditions [8,9]. Many drugs and phytoconstituents are obtained from plant-derived compounds [10]. Therapeutic efficacy needs to be improved at every stage of preparation to ensure the quality, safety, and potency without side effects and toxic effects. Hence, standardization protocols need to be improved to ensure the quality of products. Standardized herbal products of reliable quality and welldefined phytoconstituents are required for pre-clinical and clinical trials to produce beneficial therapeutic efficacy. Phytochemical compounds play a crucial role in the field of drug discovery and development of antiviral agents with significant pharmacological action $[11,12]$. Many anti-infective and anticancer drugs are derived from plant derived compounds [13]. Herbal practitioners used herbal medicine since ancient times to cure several human aliments [14]. Herbal remedies are used to treat innumerable inflictions and diseases [15]. Many phytochemical compounds obtained from herbs have been reported to have strong antiviral activity against many viral infections. These phytoconstituents must be subjected to preclinical studies and human clinical trials to determine their effectiveness and toxicity studies. Fig. 1 Represents the phytoconstituents from natural products.

\section{EXTRACTION OF PHYTOCONSTITUENTS FROM NATURAL PRODUCTS}

Extraction of phytoconstituents from medicinal plants and natural products can be extracted by maceration and hot continuous percolation or Soxhlet extraction method. The powdered plant material is extracted with solvents such as non-polar solvents, mid polar solvents, and polar solvents. Non-polar solvents include petroleum ether or benzene or hexane mainly to remove the fat soluble constituents such as fixed oils, fats, and waxes. Then extracted with solvents such as chloroform, to separate alkaloids and other secondary metabolites and mid polar solvents or lower alcohols ethanol and methanol to separate glycosides and tannins and then finally extracted with water to remove water soluble constituents. The extract obtained after extraction is subjected to evaporation/concentration using a rotary evaporator. The extract can be further subjected to isolation of phytoconstituents by column chromatography. The extract can be used for identification of active constituents by preliminary phytochemical analysis by subjecting to various chemical tests to identify alkaloids, carbohydrates, glycosides, terpenoids, tannins, flavonoids, phytosterols, phenolic compounds, steroids, etc. The concentrated product can be stored or preserved in a desiccator or refrigerator. The isolated compound can be further subjected for chromatography by thin-layer chromatography, highperformance thin-layer chromatography (HPTLC), high-performance liquid chromatography (HPLC), etc., the compound can be characterized by spectroscopic methods which include ultraviolet-Visible spectroscopy, infrared spectroscopy, NMR spectroscopy, and MASS spectroscopy methods. The characterized compound can be used for pharmacological screening by in vitro and in vivo methods using animals for preclinical evaluation and human clinical trials. The efficacy and potency of the drugs can be evaluated to know the toxicity and side effects of the compounds. The toxicity of the compound can be tested according to OECG guidelines [16]. Table 1 specifies potent active constituents against COVID-19. Fig. 2 represents the Extraction of Phytoconstituents from Medicinal Plants.

\section{THE ANTIVIRAL ACTIVITIES OF MEDICINALLY IMPORTANT PLANTS ARE PRESENTED}

\section{Anti-viral activity of $Z$. officinale}

Anti-viral activity of $Z$. officinale Ginger ingredients against the Chikungunya virus was investigated [32]. Fresh ginger $Z$. officinale has anti-viral activity against human respiratory syncytial virus in human respiratory tract cell lines [33]. Molecular docking studies of the phytocompounds of C. medica and Z. officinale were studied to find out whether these compounds could inhibit the receptor binding of SARS-CoV-2 spike protein (S protein) as well as the angiotensinconverting enzyme 2 (ACE-2), as evidenced from their docking into binding/active sites [34]. Molecular docking studies were performed on 27 phytocompounds derived from P. nigrum, Syzygium aromaticum, and $Z$. officinale roscoe was studied against protease of COVID-19. Out of 27 selected phytocompounds guaiol and gingeronone A has displayed significant inhibitory potential against coronavirus's selected targets [35]. The two compounds Tellimagrandin-II from S. aromaticum L. and O-Demethyl-demethoxy-curcumin from Curcuma longa $\mathrm{L}$. were found to be highly potential due to their higher binding affinity and significant binding free energy (MM-PBSA), along with favorable ADMET properties and stable intermolecular interactions with hotspots (including the ASN343 glycosylation site) [36].

\section{Anti-viral activity of Andrographis paniculato}

A. paniculata extract and its major component andrographolide were optimized with a high-content imaging platform and the plaque 
Table 1: Phytoconstituents present in medicinal plants and their therapeutic uses

\begin{tabular}{|c|c|c|c|}
\hline Botanical name & $\begin{array}{l}\text { Common name and family } \\
\text { name }\end{array}$ & Phyto constituents & Therapeutic uses and pharmacological activity \\
\hline Zingiber officinale rosc & Ginger zingiberaceae & $\begin{array}{l}\text { 6-gingerol, 6-shogaol, and } \\
\text { 6-paradol. Zingiberene, and } \\
\text { bisabolene }\end{array}$ & $\begin{array}{l}\text { Antibacterial, antifungal, analgesic, } \\
\text { anti-inflammatory, anticancer, antioxidant, } \\
\text { antitussive, anti-ulcer, and immunomodulatory [17] }\end{array}$ \\
\hline Piper longum L & Long pepper piperaceae & $\begin{array}{l}\text { Piperine, piperlonguminine, and } \\
\text { piperanine }\end{array}$ & $\begin{array}{l}\text { It is most commonly used to treat chronic } \\
\text { bronchitis, anti-asthmatic, laxative, gonorrhea, } \\
\text { paralysis of the tongue, antidiarrheal, cholera, } \\
\text { chronic malaria, viral hepatitis, respiratory } \\
\text { infections, stomachache, and bronchitis, diseases of } \\
\text { the spleen, cough, and tumors [18] }\end{array}$ \\
\hline Syzygium aromaticum & Clove Myrtaceae & $\begin{array}{l}\text { Eugenyl acetate, eugenol, and } \\
\beta \text {-caryophyllene }\end{array}$ & $\begin{array}{l}\text { Cloves have been documented to relieve different } \\
\text { microorganisms as scabies, cholera, antimalarial, } \\
\text { and tuberculosis [19] }\end{array}$ \\
\hline Tragia involucrate $\mathrm{L}$ & Euphorbiaceae & $\begin{array}{l}\text { Stigmosterol, Squalene and } \\
\gamma \text {-Sitosterol }\end{array}$ & $\begin{array}{l}\text { T. involucrata leaf has been traditionally used as } \\
\text { anti-inflammatory, wound healing, dermatitis, } \\
\text { scabies, and skin diseases. It has also been found to } \\
\text { be effective in treating pain and bronchitis [20] }\end{array}$ \\
\hline Anacyclus pyrethrum & Asteraceae & $\begin{array}{l}\text { Alkaloids, tannins. triterpenes, } \\
\text { flavonoids, sterols, some trace } \\
\text { metals and phenols }\end{array}$ & $\begin{array}{l}\text { Anti-rheumatic, analgesic, antibacterial, antiviral, } \\
\text { carminative, anti-catarrh, improve digestion, } \\
\text { antidiabetic, immunostimulating effect, inhibitory } \\
\text { effects, antidepressant activity, anticonvulsant } \\
\text { activity, memory-enhancing activity, antimicrobial } \\
\text { activity, and antioxidant [21] }\end{array}$ \\
\hline Andrographis paniculata & Acanthaceae & $\begin{array}{l}\text { Andrographolide diterpenoids, } \\
\text { flavonoids and polyphenols }\end{array}$ & $\begin{array}{l}\text { Andrographis is used for common cold, } \\
\text { osteoarthritis, infection of the throat and tonsils, } \\
\text { and a type of inflammatory bowel disease [22] }\end{array}$ \\
\hline Hygrophilla auriculata & Acanthaceae & Lupeol and Betulin & $\begin{array}{l}\text { Analgesic, antitumor, antioxidant, hepatoprotective, } \\
\text { hypoglycemic, hematinic, diuretics, free-radical } \\
\text { scavenging, anthelmintic, anti-inflammatory, } \\
\text { antipyretic, and anabolic [23] }\end{array}$ \\
\hline Terminalia chebula Retz. & $\begin{array}{l}\text { Chebulic myrobalan } \\
\text { Combretaceae }\end{array}$ & $\begin{array}{l}\text { Gallic acid, ellagic acid, chebulic } \\
\text { acid, chebulagic acid }\end{array}$ & $\begin{array}{l}\text { Terminalia is most commonly used for heat } \\
\text { ailments including heart failure and chest pain. It is } \\
\text { also used for diabetes, high cholesterol and many } \\
\text { other conditions [24] }\end{array}$ \\
\hline Justicia adhatoda L. & Vasaka Acanthaceae & $\begin{array}{l}\text { The most important is vasicinone } \\
\text { and vasicine, a quinazoline } \\
\text { alkaloid }\end{array}$ & $\begin{array}{l}\text { Malabar nut is used to loosen chest congestion, } \\
\text { open the breathing tubes (bronchi), and treat } \\
\text { spasms. It is used for upper airway infections, } \\
\text { antitussive, bronchitis, and anti-TB [25] }\end{array}$ \\
\hline $\begin{array}{l}\text { Plectranthus } \\
\text { amboinicus (Lour) } \\
\text { Spreng }\end{array}$ & Lamiaceae & $\begin{array}{l}\text { Carvacrol Cirsimaritin and } \\
\text { Chrysoeriol }\end{array}$ & $\begin{array}{l}\text { Plectranthus amboinicus has been used in herbal } \\
\text { medicines for the treatment of various disorders } \\
\text { such as asthma, flu, eczema, and cardiovascular } \\
\text { disorders [26] }\end{array}$ \\
\hline Costus speciosus & Costaceae & Costunolide, Luteolin and lupeol & $\begin{array}{l}\text { These plants have been known to demonstrate } \\
\text { pharmacological activities such as } \\
\text { anti-inflammatory, antimicrobial, antioxidant, } \\
\text { anti-dyslipidemic, and anti-cancer [27] }\end{array}$ \\
\hline $\begin{array}{l}\text { T. cordifolia (Willd.) } \\
\text { Miers ex Hook.f\&Thoms }\end{array}$ & Menispermaceae & $\begin{array}{l}\text { Tinosponone Major constituent } \\
\text { of T. cordifolia: terpenoid, } \\
\text { alkaloid, lignans, steroids }\end{array}$ & $\begin{array}{l}\text { T. cordifolia is used for diabetes, high cholesterol, } \\
\text { allergic rhinitis, upset stomach, gout, lymphoma } \\
\text { and other cancers, rheumatoid arthritis, hepatitis, } \\
\text { peptic ulcer disease, fever, gonorrhea, syphilis, and } \\
\text { to boost the immune system [28] }\end{array}$ \\
\hline Clerodendrum serratum L. & Verbenaceae & Bharangin Scutellarein & $\begin{array}{l}\text { Respiratory diseases treatment of pain, } \\
\text { inflammation, rheumatism, and fever especially } \\
\text { malarial fever [29] }\end{array}$ \\
\hline Sida acuta Burm. f. & Malvaceae & Magnoflorine & $\begin{array}{l}\text { Sida acuta Burm. f., Malvaceae, is regarded as } \\
\text { astringent, tonic and useful in treating urinary } \\
\text { diseases and blood disorders, bile, liver and as } \\
\text { treatment for nervous diseases [30] }\end{array}$ \\
\hline Cypreus rotundus $\mathrm{L}$. & Сyperaceae & Cyperene & $\begin{array}{l}\text { Used for conditions such as anti-diabetic, } \\
\text { anti-diarrheal, indigestion, and apply it to the skin } \\
\text { for acne, dandruff, and many other conditions [31] }\end{array}$ \\
\hline
\end{tabular}

T. cordifolia: Tinospora cordifolia

assay for viral output study using the legitimate model of human lung epithelial cells, Calu-3, to determine anti-SARS-CoV-2 activity [37]. Andrographolide from $A$. paniculata as a potential inhibitor of the main protease of SARS-COV-2 (Mpro) through in silico studies such as molecular docking, target analysis, toxicity prediction, and ADME prediction were evaluated [38]. 
In silico molecular docking studies on Kabasura Kudineer showed that Acetoside, Luteolin 7 -rutinoside rutin, Chebulagic acid, Syrigaresinol, Acanthoside, Violanthin, Andrographidine C, myricetin, Gingerenone -A, Tinosporinone, Geraniol, Nootkatone, Asarianin, and Gamma sitosterol are main compounds from KK plants which may inhibit COVID-19 [39].

\section{Anti-viral activity of Justicia adhatoda}

Synergistic antiviral effects against SARS-CoV-2 by plant-based molecules were investigated [40]. The alkaloids from leaf extracts of J. adhatoda have also been reported to possess anti-viral activity [41]. Three compounds such as anisotine and vasicoline of J. adhatoda and Pemirolast are very good inhibitors and effective against protease inhibitor and replicase inhibitor of COVID-19 virus using COVID-19 Docking Server [42]. The acetone and methanol extracts of Moringa oleifera, Adhatoda vasica, and Cassia fistula were tested against sputum samples of 120 patients suffering from respiratory tract infection (RTI), tuberculosis infection, and multidrug resistant (MDR) isolates. MDR strains, showed remarkable sensitivity against all the three plants [43].

The study revealed that Plectranthus amboinicus as the inhibitor of novel coronavirus (COVID-19) targets, that is, 3CLpro, PLpro, and spike protein, through in silico molecular docking and other computational approaches against COVID-19 [44].

Saussurea costus has immunomodulatory effects on cytokine release and has complement-inhibitor substances helpful in the treatment of

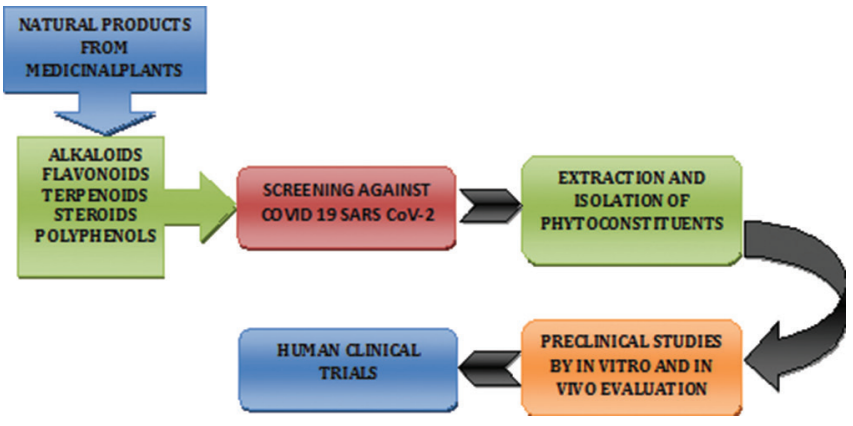

Fig. 1: Phytoconstituents from natural products some diseases related to marked activation of the complement system, like respiratory distress [45].

\section{Anti-viral activity of Tinospora cordifolia}

Based on the therapeutic significance, the chemical constituents from the extract of T. cordifolia belonging to various classes such as alkaloids, lignans, steroids, and terpenoids are investigated as potential drug candidates for COVID-19 [46]. In silico molecular docking studies were performed on T. cordifolia containing five compounds such as berberine, $\beta$-sitosterol, coline, tetrahydropalmatine, and octacosanol, $3 \mathrm{CL}^{\text {pro }}$ is used to study drug:3CL pro interactions and thus to investigated to be used as an anti-viral drug against SARS-CoV-2 [47]. Molecular docking study showed six probable inhibitors against SARS-CoV-2 Mpro (Main protease), two from Withania somnifera (Ashwagandha) Withanoside $\mathrm{V}$ and Somniferine, one from T. cordifolia (Giloy) (Tinocordiside), and three from Ocimum sanctum (Tulsi) (Vicenin, Isorientin 4'-O-glucoside 2 "-O-p-hydroxybenzoagte and Ursolic acid) [48]. In silico molecular docking approach has been carried out to dock the ligands (various secondary metabolites from T. cordifolia) to the target (SARS-CoV-2 main protease) and compared its efficacy against standard drugs (Azithromycin, Chloroquine, Hydroxychloroquine, Favipiravir, and Remdesivir). Columbin, Tinosporide, N-trans-feruloyl-tyraminediacetate, Amritoside C, Amritoside B, Amritoside A, Tinocordifolin, Palmatoside G, Palmatoside F, and Maslinic acids are other molecules considered to be the key molecules based on their docking score [49]. The aqueous extracts of T. cordifolia (willd.) Hook. f. and Thomson in the form of Giloy Ghanvati, as a means of treatment to the SARS-CoV-2 spike-protein induced disease phenotype in a humanized zebrafish model were evaluated [50].

The active compounds of selected Ayurveda medicines recommended for COVID-19 was investigated against SARS-CoV-2 [51].

The molecular docking studies of 200 ligands were studied out of them best ten were selected based on drug discovery parameters such as S-score, ligand interactions, hydrophobic interactions, and drug likeness. The ten best selected ligands were found to be verbenalin, epigallocatechin, swertisin, nobiletin, pinoresinol, caftaric acid, hesperetin, islandicin, neochlorogenic acid, and sesamin that exploit the potency as antagonists of viral protein. Among binding interactions

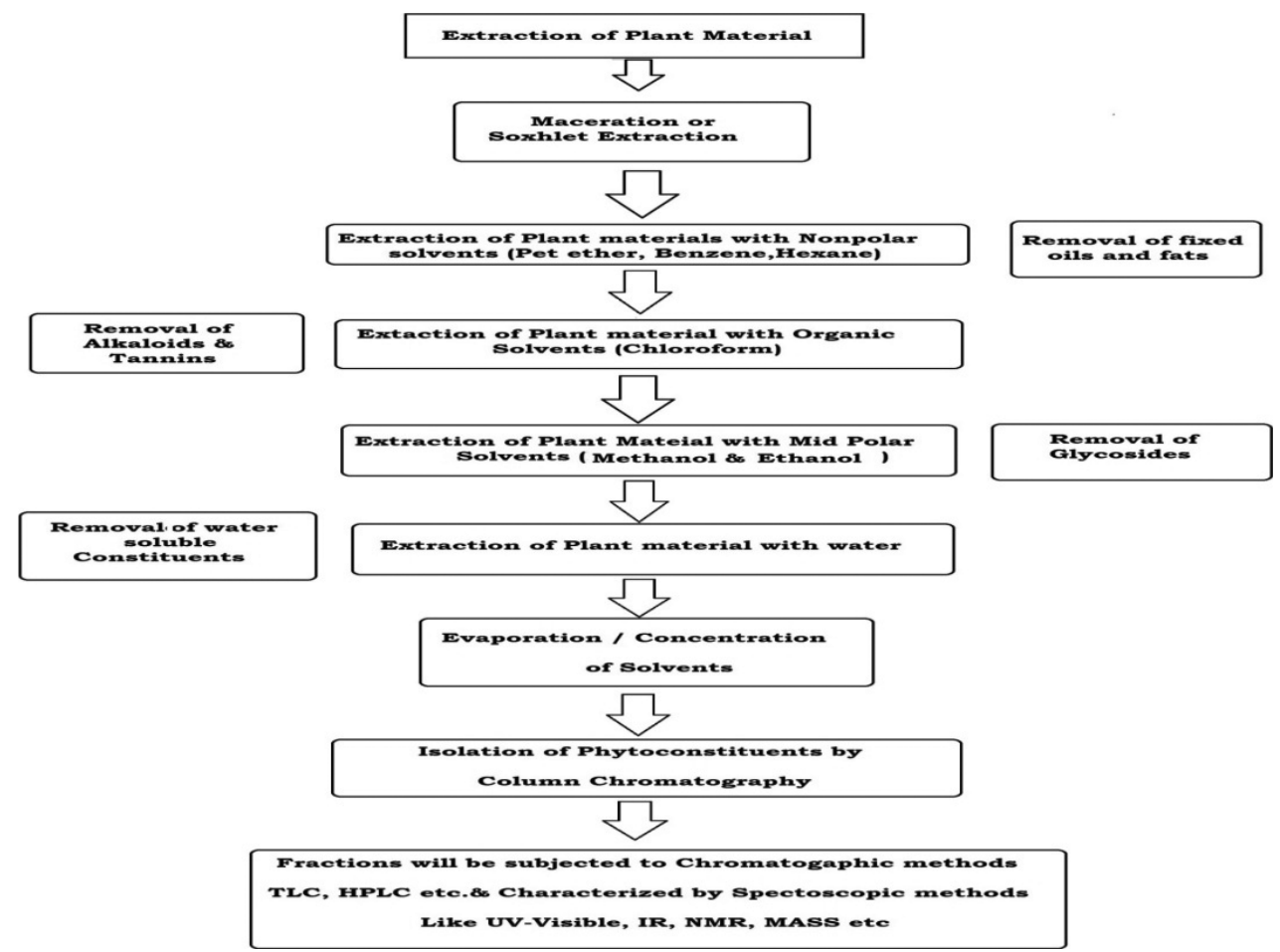

Fig. 2: The extraction of phytoconstituents from medicinal plants 

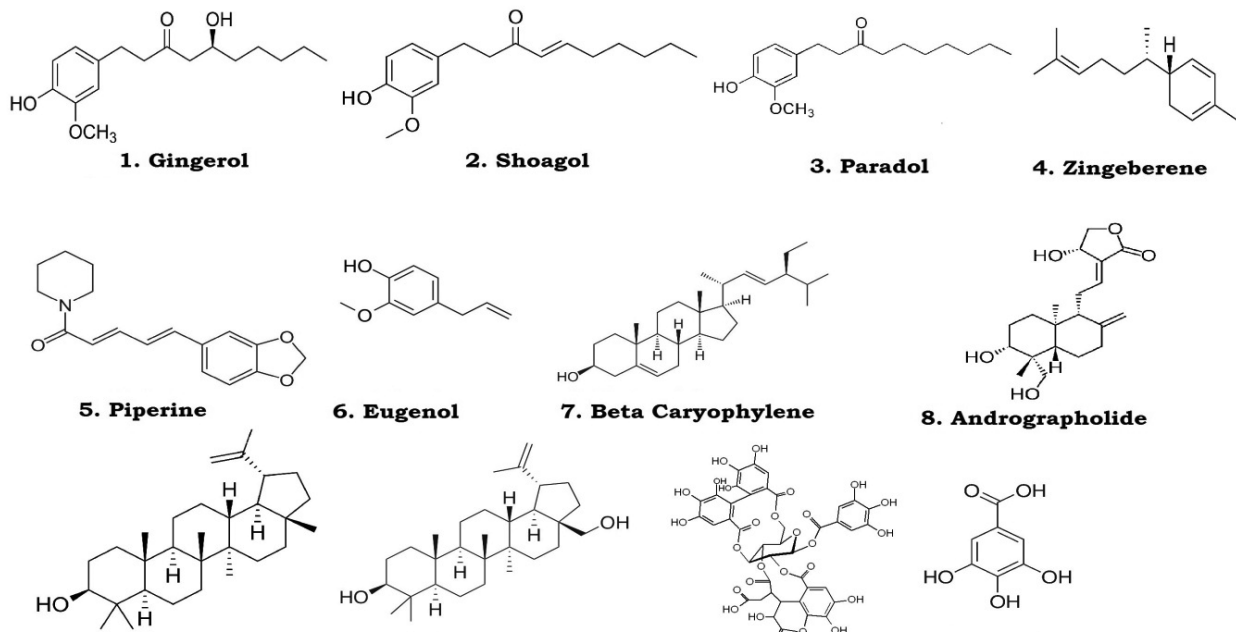

6. Eugeno1

7. Beta Caryophylene

3. Paradol

4. Zingeberene

9. Lupeol<smiles>C=C(C)C1CCC2(CO)CCC3C(CCC4C5CCC(O)C(C)(C)C5CCC34C)C12</smiles>

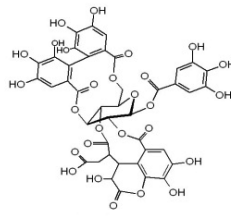

8. Andrographolide

10. Betulin

11. Chebulagic acid

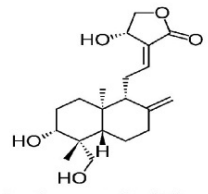<smiles>O=C(O)c1cc(O)c(O)c(O)c1</smiles><smiles>O=c1c2ccccc2nc2n1CC[C@H]2O</smiles><smiles>COc1cc2oc(-c3ccc(O)cc3)cc(=O)c2c(O)c1OC</smiles>

14. Crisimaritin<smiles>COc1cc(-c2cc(=O)c3c(O)cc(O)cc3o2)ccc1O</smiles>

13. Vasicinone

15. Chrysoeriol<smiles>C=C1C(=O)O[C@@H](/C=C/C(C)=C\CC/C(C)=C/C)C1CC</smiles>

16. Costunolide

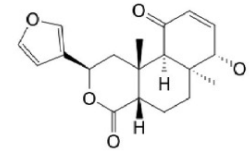

17. Tinosponone<smiles>CC(C)C1=CC2=CC=C3C(C)(C)CC(=O)OC3(C)C2=C(O)C1=O</smiles>

18. Bharangin<smiles>O=c1cc(-c2ccc(O)c(O)c2)oc2cc(O)ccc12</smiles>

19. Scutellrein<smiles>COc1cc2c(c(O)c1O)-c1c(ccc(OC)c1O)C1(CCCN1C)C2</smiles>

20. Magnoflorine

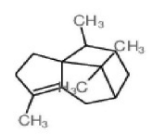

21. Cyprene

Fig. 3: The structure of bioactive phytoconstituents

of all ligands, Arg339 centered as the main interacting residue among almost all the ligands [52].

A molecular docking analysis was carried out using 171 essential oil components with SARS-CoV-2 main protease. The compound with the best normalized docking score to SARS-CoV-2 $\mathrm{M}^{\text {pro }}$ was the sesquiterpene hydrocarbon $(E)$ - $\beta$-farnesene. Essential oils may potentiate other antiviral agents, or they may provide some relief of COVID-19 symptoms [53]. The structures of bioactive phytoconstituents are depicted in Fig. 3.

Antiviral activity of two important Siddha Polyherbal formulations Kaba Sura Kudineer and Nilaveembu Kudineer (NVK)

The efficacy of NVK as an antiviral formulation against CHIKV and DENV was undertaken. This study provides insights to the possible mode of action of NVK in in vitro condition during CHIKV and DENV infection [57]. The phytoconstituents present in medicinal plants with therapeutic uses and pharmacological activity are represented in Table 2. The chemical structures of active phytoconstituents are depicted in Fig. 4.

The effectiveness of the KSK and NVK along with standard Allopathy Treatment was determined to compared with Placebo (Decaffeinated Tea) with standard Allopathy Treatment in the management of
Symptomatic COVID-19 patients and also in reduction of Hospital Stay Time and Changes in Immunological (IL6) and Bio Chemical Markers (Ferritin, CRP, D-Dimer and LDH) [58].

The interaction of 47 active components identified from the ten different medicinal plants was investigated against the structural targets of SARS-CoV-2 (Mpro and spike protein) and human ACE2 receptor was explored through molecular docking analysis. The bioactive ligands such as Cucurbitacin E, Orientin, Bis-andrographolide, Cucurbitacin B, Isocucurbitacin B, Vitexin, Berberine, Bryonolic acid, Piperine, and Magnoflorine targeted the hotspot residues of SARS-CoV-2 main protease. The study emphasized that Cucurbitacin E and orientin could serve as a promising scaffold for developing anti-COVID-19 drug [59].

The in silico computational studies of phytoconstituents of Siddha official formulation Kabasura Kudineer and novel herbal preparation - JACOM could be affective against the ongoing pandemic novel coronavirus disease SARS-CoV-2. Totally, 37 compounds were screened, of these nine compounds showed high binding affinity against SARS$\mathrm{CoV}-2$ spike protein. Based on these, the new formulation called as "SNACK-V" was proposed. Based on further experiments and clinical trials, these formulations could be used for effective treatment of COVID-19 [60]. 
<smiles>CC(C)=C1CCC2=CC(=O)C[C@@H](C)[C@]2(C)C1</smiles>

1. Alpha Vetivone<smiles>O=c1cc(-c2ccc(O)c(O)c2)oc2c(C3OC(O)C(CO)CC3O)c(O)cc(O)c12</smiles>

4. Orientin<smiles>C/C(=C/CCC1(C)CC2CCC1C2)CO</smiles>

2. Alpha Santalo<smiles>C/C(=C/CC1CC2CCC1C2)CO</smiles>

3. Beta Santalo1<smiles>O=c1cc(-c2ccc(O)cc2)oc2c(C3OC(CO)[C@@H](O)[C@H](O)[C@H]3O)c(O)cc(O)c12</smiles>

5. Vitexin<smiles>O=C1Oc2c(O)c(O)cc3c2C2(CC(O)=CC13O)OC2=O</smiles>

6. Ellagic acid<smiles>CC1CC[C@]2(NC1)O[C@H]1C[C@H]3[C@@H]4CC=C5C[C@@H](O)CC[C@]5(C)[C@H]4CC[C@]3(C)[C@H]1[C@H]2C</smiles>

7. Solasodine

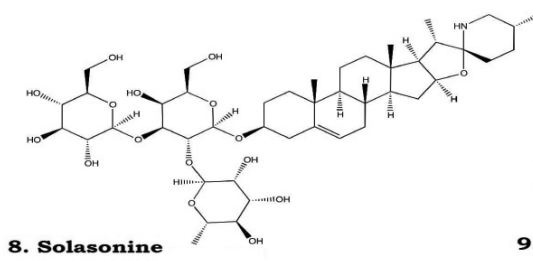<smiles></smiles>

9. Berberine

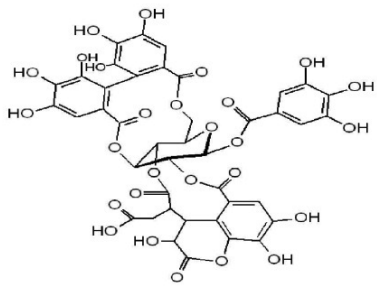

11. Chebulagic acid

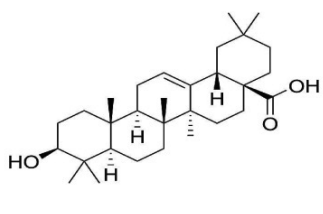

12. Oleanolic acid

Fig. 4: Chemical structures of active phytoconstituents

Table 2: The table specifies few medicinal plants and their phytoconstituents with pharmacological activity

\begin{tabular}{|c|c|c|c|}
\hline Botanical name & Common name and family name & Phytoconstituents & Therapeutic uses and pharmacological activity \\
\hline Vetiveria & Poaceae & $\alpha$-vetivone & $\alpha$-Vetivone is an organic compound that is classified as a \\
\hline Zizanioides & & & $\begin{array}{l}\text { sesquiterpene. It is a major component of the oil of vetiver, which } \\
\text { is used to prepare certain high value perfumes [54] }\end{array}$ \\
\hline Santalum Album & Santalaceae & Santalol & $\begin{array}{l}\text { White sandalwood is used for treating the common cold, cough, } \\
\text { bronchitis, fever, and sore mouth and throat. It is also used to } \\
\text { treat urinary tract infections, liver disease, gallbladder problems, } \\
\text { heatstroke, gonorrhea, headache, and conditions of the heart and } \\
\text { blood vessels [55] }\end{array}$ \\
\hline Mollugo cerviana & Molluginaceae & Orientin, Vitexin & $\begin{array}{l}\text { Antioxidant, anti-aging, antiviral, antibacterial, } \\
\text { anti-inflammation, vasodilatation and cardioprotective, } \\
\text { radiation protective, neuroprotective, antidepressant-like, } \\
\text { antiadipogenesis, and antinociceptive effects [55] }\end{array}$ \\
\hline Solanum nigrum & Solanaceae & $\begin{array}{l}\text { Solasodine, } \\
\text { Solasonine, } \\
\text { Solamargine }\end{array}$ & $\begin{array}{l}\text { Literature survey reveals that solasodine has diuretic, anticancer, } \\
\text { antifungal, cardiotonic, antispermatogenetic, antiandrogenic, } \\
\text { immunomodulatory, antipyretic, and various ef } \\
\text { fects on central nervous system [56] }\end{array}$ \\
\hline
\end{tabular}

The antiviral activity of bioactive phytoconstituents are presented The new lignan glycoside from Calotropis gigantea, $(+)$-pinoresinol 4-0-[6"-O-vanilloyl]- $\beta$-D-glucopyranoside (1) and two known phenolic compounds, 6'-0-vanilloyltachioside (2) and 6'-0-vanilloylisotachioside (3) may have therapeutic potential in influenza virus infection through inhibition of NF- $\kappa B$ pathway and viral ribonucleoproteins nuclear export [79]. Medicinal plants and their phytoconstituents with pharmacological activity are specified in Table 3 The chemical structures of phytoconstituents are depicted in Fig. 5.
Agele marmelos bael fruit ethanolic extract have shown antiviral activity against Ranikhet disease virus. Marmilide is the most effective viricidal agent interfering with early events of replicating cycle. Thus, bael fruit has better viricidal potential and may be exploited as a potent antiviral agent in near future [80].

E. jambolana cold and hot aqueous extracts of bark and hot aqueous extract of leaves showed significant virucidal activity against H5N1 virus (100\% inhibition) which was further confirmed in virus yield reduction assay (-98-99\% reduction) and by egg based in vivo assay [81] 

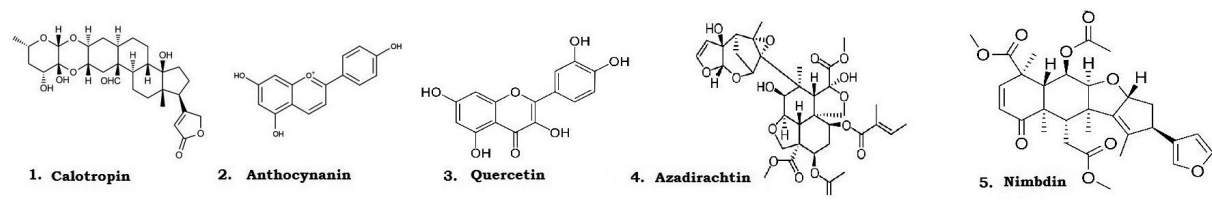

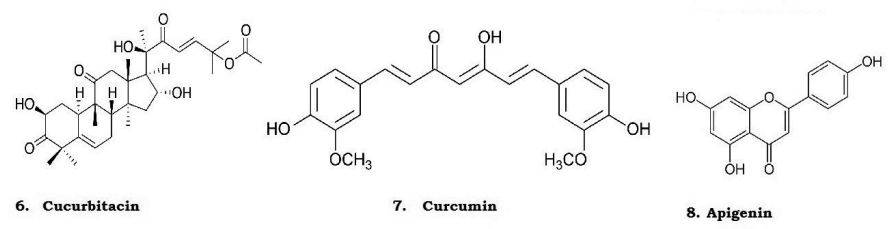<smiles>CC1=CC(=O)C(C(C)C)=CC1=O</smiles>
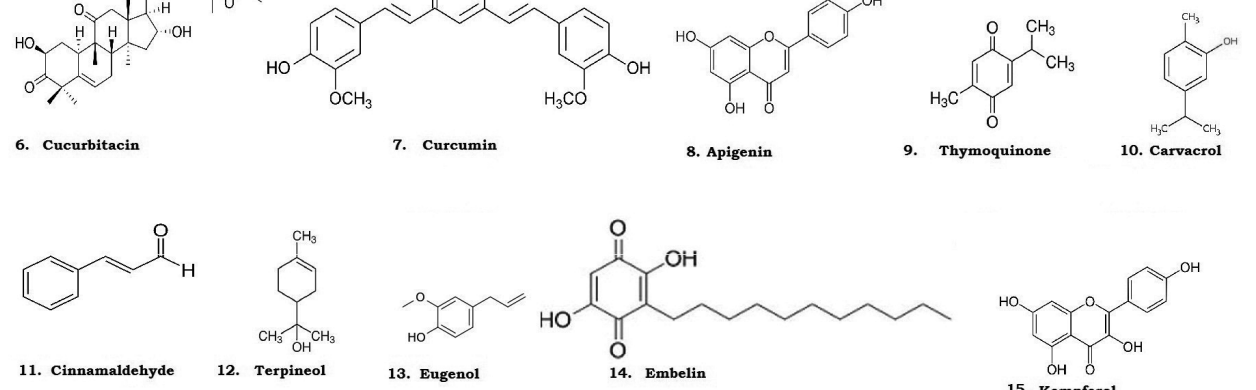<smiles>C=CCc1ccc(OC)c(OC)c1</smiles>

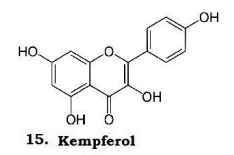<smiles>O=C(/C=C/C=C/c1ccc2c(c1)OCO2)N1CCCCC1</smiles><smiles>C=CCc1cc(OC)c2c(c1)OCO2</smiles>

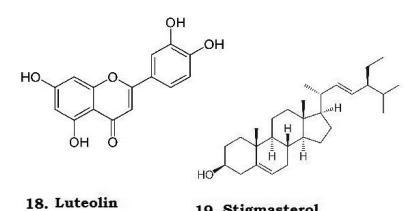<smiles></smiles>

Fig. 5: The chemical structure of phytoconstituents

\section{Antiviral activity of Azardirachta indica}

Molecular docking studies identified three potential compounds from leaf extracts of neem (Nimbaflavone, Rutin, and Hyperoside) against Influenza virus strains having perfect binding with reported conserved residues (ASP302, SER50) of influenza virus nucleoprotein that is involved in the binding of drugs. Hyperoside from neem leaf extract along with drugs LGH, Naproxen, BMS-885838, and BMS-883559 showed best interactions with conserved residues of nucleoprotein [82]. The aqueous extract preparation from the barks of neem plant $A$. indica acts as a potent entry inhibitor against herpes simplex virus type-1 (HSV-1) infection into natural target cells [83]. Antibacterial as well as antiherpes virus activity of sulfonoquinovosyldiacylglyceride, a glycolipid, isolated from the leaves of $A$. indica has been described [84]. A total of 70 compounds from ( $A$. indica or Neem) were virtually screened against these two proteins and further analyzed with molecular dynamics simulations, which resulted in the identification of a few common compounds with strong binding to both structural proteins. The compounds bind to biologically critical regions of $\mathrm{M}$ and $\mathrm{E}$, indicating their potential to inhibit the functionality of these components. The computational approach may result in the identification of effective inhibitors of SARS-CoV-2 assembly [85]. The inhibitory activity of Neem extracts on Papain like protease (PLpro) of the novel coronavirus SARS-CoV-2 was examined. Desacetylgedunin (DCG) found in Neem seed showed the highest binding affinity toward PLpro. The significant effect of DCG on PLpro may help in therapeutic efforts against SARS-CoV-2 [86].

The possible effects of Nigella sativa were determine on immuneresponse and pathogenesis of H9N2 avian influenza virus in turkeys [87].

\section{Antiviral activity of $C$. longa}

The antiviral activity of curcumin and its new derivatives such as gallium-curcumin and Cu-curcumin on replication of HSV-1 in cell culture was designed. The study was performed as an in vitro study in which the antiviral activity of different concentrations of three substances including curcumin, Gallium-curcumin, and Cu-curcumin was tested on HSV-1. The cytotoxicity of the tested compounds was also evaluated on the Vero cell line. Curcumin and its new derivatives have remarkable antiviral effects on HSV-1 in cell culture [88]. The antiviral activity of $C$. longa Linn (CLL) against HBV replication in liver cells was investigated. Aqueous extract of CLL was prepared and used to analyze its antiviral activity against HBV replication in HepG 2.2.15 cells, which contain HBV genomes. CLL extract can be used as a safe and specific drug for patients with liver diseases caused by HBV infection [89].

\section{Antiviral activity of Piper longum and P. nigrum}

The ethanolic extract of $P$. longum Linn was screened against in vitro antiHBV activity by using Hep G 2.2.15 cell line. The compound piperine (7) possessed remarkable inhibitory HBV activity, against the secretion of hepatitis B virus surface antigen and hepatitis B virus e antigen with the Selectivity Index values of 15.7 and 16.8, respectively [90]. Ten piperamides from $P$. nigrum were isolated from a combined methanol/ dichloromethane extract (PNE) of black pepper fruits, and investigated for (1) their antiviral properties against three viruses related to the upper RTIs, and (2) their anti-proliferative activity in vascular smooth muscle cells, which is a key element in the prevention of restenosis. The extract of P. nigrum was found to inhibit coxsackie virus type B3 [91].

Smilax china L. was evaluated for anti-HIV-1 activities and cytotoxicity activities in vitro L: Four extracts ( $\mathrm{EtOH}, \mathrm{CHCl} 3, \mathrm{EtOAc}$, and $\mathrm{BuOH}$ ) and five phenolics (dihydrokaempferol (1), resveratrol (2), kaempferol-70 - $\beta$-D-glucoside (3), dihydrokaempferol-3-0- $\alpha$-L-rhamnoside (4), and oxyresveratrol (5)) [92].

\section{Antiviral activity of Phyllanthus niruri}

The antiviral activity of the aqueous extract of four Phyllanthus species was evaluated against HSV-1 and HSV-2 in Vero cells by quantitative PCR [93]. P. niruri ethanol extract was evaluated for its anti$\mathrm{HCV}$ activities. Anti-HCV activity was determined by in vitro culture cells of Huh 7it. Docking analysis was performed to predict the interaction phyllanthin and hypophyllantin, known compounds of $P$. niruri against $\mathrm{HCV}$ receptor. The ethanol extract of $P$. niruri may be good candidates for the development of anti-HCV drugs [94]. In vitro antiviral activity against HSV-1 was evaluated, 28 extracts corresponding to 24 plant species and 4 alga species were assayed. Six of the methanolic extracts inactivated viral particles by direct interaction and 14 presented antiviral activity when incubated with cells already infected. Most interesting antiviral 
Table 3: The table specifies few medicinal plants and their phytoconstituents with pharmacological activity

\begin{tabular}{|c|c|c|c|}
\hline Botanical name & Common name and family name & Phytoconstituents & Therapeutic uses and pharmacological activity \\
\hline $\begin{array}{l}\text { Calotropis } \\
\text { gigantea }\end{array}$ & Apocynaceae & $\begin{array}{l}\text { The plant contains } \\
\text { Calotropogenin }\end{array}$ & $\begin{array}{l}\text { Calotropis is use for anti-inflammatory, antiepileptic, } \\
\text { antipyretic, antispasmodics, antileprotic, and } \\
\text { anticancer [61] }\end{array}$ \\
\hline Aegle marmelos & Bael Rutaceae & $\begin{array}{l}\text { Marmelosin, } \\
\text { marmin and } \\
\text { Anthocyanin }\end{array}$ & $\begin{array}{l}\text { Bael is used as laxative, anti-diarrheal, anti-diabetes, } \\
\text { and other conditions; anti-inflammatory, } \\
\text { antiasthmatic, anti-diarrhea, and antidiabetic [62] }\end{array}$ \\
\hline $\begin{array}{l}\text { Eugenia } \\
\text { jambolana }\end{array}$ & Java plum Myrtaceae & Quercetin & $\begin{array}{l}\text { It is used to relieve flatulence, anti-inflammatory, gastritis, } \\
\text { laxative, anti-diarrheal, and other conditions [63] }\end{array}$ \\
\hline $\begin{array}{l}\text { Azadirachta } \\
\text { indica }\end{array}$ & Meliaceae & $\begin{array}{l}\text { Azadirachtin and the } \\
\text { others are nimbin, } \\
\text { nimbidin, nimbidol }\end{array}$ & $\begin{array}{l}\text { Neem is used for tooth plaque, gum } \\
\text { disease (gingivitis), lice, to repel insects and for other } \\
\text { conditions [64] }\end{array}$ \\
\hline Luffa echinata & Bitter sponge guard Cucurbitaceae & $\begin{array}{l}\text { Contains chrysoeriol, } \\
\text { the seeds contain } \\
\text { cucurbitacin B, } \\
\text { sapogenin }\end{array}$ & $\begin{array}{l}\text { Luffa is used for treating and preventing colds, nasal } \\
\text { swelling and sinus problems. It is also used for } \\
\text { chronic pain such as arthritis pain, muscle pain, and } \\
\text { chest pain [65] }\end{array}$ \\
\hline $\begin{array}{l}\text { Cinnamom } \\
\text { zeylanicum }\end{array}$ & Ceylon cinnamon Lauraceae & Cinnamadehyde & $\begin{array}{l}\text { Cinnamon is used for indigestion problems dyspepsia, } \\
\text { anti-diarrheal, anti-diabetic, obesity, and other } \\
\text { conditions [67] }\end{array}$ \\
\hline Curcuma longa & Tumeric Zingiberaceae & Curcumin & $\begin{array}{l}\text { Turmeric is commonly used for conditions } \\
\text { involving analgesic and anti-inflammatory, such as } \\
\text { osteoarthritis. It is also used for hay fever, depression, } \\
\text { anti-hyperlipidemia, hepatoprotective, and itching. } \\
\text { Turmeric is use for heartburn, cognition, inflammatory } \\
\text { bowel disease, stress, and many other conditions [68] }\end{array}$ \\
\hline Piper cubebe & Tailed pepper Piperaceae & Terpineol & $\begin{array}{l}\text { Cubebs are used as anti-parasitic, antibacterial, } \\
\text { antidiarrheal, gonorrhea, prostate cancer, anticancer, } \\
\text { and many other conditions [69] }\end{array}$ \\
\hline Smilax china & Smilacaceae & $\begin{array}{l}\text { Astilbin, flavonone } \\
\text { glycoside }\end{array}$ & $\begin{array}{l}\text { Sarsaparilla is used to treat skin diseases, rheumatoid } \\
\text { arthritis (RA), kidney disease, sexually transmitted } \\
\text { diseases, and many other conditions [71] }\end{array}$ \\
\hline Acalypha indica & Euphorbiaceae & $\begin{array}{l}\text { Kaempferol } \\
\text { glycosides }\end{array}$ & $\begin{array}{l}\text { Acalypha used in diseases of the teeth and gums, } \\
\text { burns, toxins of Plant and mixed origin, stomach } \\
\text { pain, diseases due to Pitha, bleeding piles, irritations, } \\
\text { stabbing pain, wheezing, and sinusitis [72] }\end{array}$ \\
\hline Piper longum & Long pepper Piperaceae & Piperine alkaloid & $\begin{array}{l}\text { Long pepper is used for gastrointestinal problems, } \\
\text { anti-asthmatic, antiarthritic, problems during } \\
\text { menstruation and many other conditions [73] }\end{array}$ \\
\hline $\begin{array}{l}\text { Myristica } \\
\text { fragrans }\end{array}$ & Nutmeg Myristicaceae & Myristicin & $\begin{array}{l}\text { As anti-inflammatory, antioxidant, antibacterial, } \\
\text { antifungal, antiobesity, antidiabetic, and anticancer } \\
\text { activities, together with analgesic, chemopreventive, } \\
\text { hepatoprotective, neuropharmacologic, } \\
\text { cardioprotective, toxicological, and other } \\
\text { pharmacological effects [74] }\end{array}$ \\
\hline Phylanthus niruri & Gale of the wind Phyllanthaceae & $\begin{array}{l}\text { Embelin, other } \\
\text { flavonoids }\end{array}$ & $\begin{array}{l}\text { Chanca piedra is used in the treatment of urolithiasis. } \\
\text { It is also used for various disorders of the urinary tract } \\
\text { infections, digestive tract, and hepatoprotective [75] }\end{array}$ \\
\hline Eclipta alba & False daisy Asteraceae & $\begin{array}{l}\text { Luteolin like } \\
\text { flavonoids and } \\
\text { sterols like } \\
\text { stigmasterol }\end{array}$ & $\begin{array}{l}\text { Pharmacological activities of plant extracts and } \\
\text { individual phytoconstituents have revealed } \\
\text { anticancer, hepatoprotective, anti-inflammatory, and } \\
\text { antimicrobial properties [76] }\end{array}$ \\
\hline Pedalium murex & Pedalium Pedaliaceae & $\begin{array}{l}\text { Triterpenoids and } \\
\text { flavonoids flavones }\end{array}$ & $\begin{array}{l}\text { P. murex plant parts are routinely and widely used } \\
\text { for the treatment of various ailments of humans } \\
\text { and livestock. Reproductive and urinary tract } \\
\text { ailments [77] }\end{array}$ \\
\hline $\begin{array}{l}\text { Solanum } \\
\text { melongena var } \\
\text { insanum }\end{array}$ & Aubergine Solanaceae & $\begin{array}{l}\text { Phenolic acids and } \\
\text { flavonoids }\end{array}$ & Potent antioxidant properties [78] \\
\hline
\end{tabular}


activity values obtained are those of Limonium brasiliense, Psidium guajava, and $P$. niruri, which inhibit HSV-1 replication in vitro with $50 \%$ effective concentration $\left(\mathrm{EC}_{50}\right)$ values of 185,118 , and $60 \mu \mathrm{g} / \mathrm{mL}$, respectively [95]. Four species of Phyllanthus were evaluated against anti-dengue agent ( $P$. amarus, $P$. niruri, $P$. urinaria, and $P$. watsonii) and their polyphenolic compounds were identified through HPLC and LC-MS/MS analysis. MTS assay was then carried out to determine the maximal non-toxic dose of the extracts, followed by screening of the in vitro antiviral activity of aqueous cocktail extracts against DENV2 by means of time-of-addition (pre-, simultaneous, and post-) using RTqPCR. Several active compounds including gallic acid, geraniin, syringin, and corilagen were identified. Phyllanthus showed strongest inhibitory activity against DENV2 with more than $90 \%$ of virus reduction in simultaneous treatment [96].

The anti-hepatitis C virus activity was evaluated in the Eclipta alba extract, bioassay based fractionation and identify anti-HCV phytochemicals from the active fractions were performed. Eclipta alba extract strongly inhibited RNA dependent RNA polymerase (RdRp) activity of HCV replicase in vitro. The identified compounds were wedelolactone, luteolin, and apigenin Bioassay-based fractionations [97]

Antioxidative, cytoprotective properties, and anti-HSV-1 activity were studied, antiviral activity was studied in Vero cells. Results highlighted different compositions of the extracts, with chlorogenic acid and delphinidin-3-rutinoside as the major constituents [98].

\section{CONCLUSION AND FUTURE PERSPECTIVES}

Preclinical studies in laboratory animal models and clinical studies are needed to prove the efficacy of these phytocompounds in inhibiting coronavirus. Conducting human clinical trials and observing the efficacy to reduce the multiplication of the virus. The introduction of plant products should be incorporated in food as nutraceuticals, because these are preparations from natural products, obtained from plants can act as immunomodulators. It is also necessary to conduct preclinical studies in vitro and in vivo on animals and clinical trials on patients to confirm their effectiveness in inhibiting COVID-19. The development of phytopharmaceuticals as an alternative approach could be seen as a potential treatment option against SARS-CoV-2 in current COVID-19 pandemic. Scarcity of the drugs and specific treatments for COVID-19 till date motivate the researchers to search for new alternatives for successfully combating the virus. The low toxicity and decreased side effects of herbal medicines and an easy development process provide additional advantages in their fast and wide usage. This review presents the essential information of plant extracts and phytoconstituents in the development of formulations with phytochemical compounds obtained from medicinal plants. Further investigation for future studies is recommended on naturally derived plant products alone or in integration with western medicine. However, further in vivo and in vitro studies need to be done to confirm the bioactivity of these compounds against COVID-19. The article was compiled from various literatures and it was an easy access to collect information from most of the articles published on COVID-19, since many articles were from open access journals.

\section{ACKNOWLEDGMENTS}

Declared none.

\section{AUTHOR CONTRIBUTION}

All the authors have equally contributed to the article.

\section{CONFLICT OF INTEREST}

The authors have no conflict of interest.

\section{SOURCE OF FUNDING}

Nil.

\section{REFERENCES}

1. Singhal T. A review of coronavirus disease-2019 (COVID-19). Indian J Pediatr 2020;87:281-6.

2. Wiersinga WJ, Rhodes A, Cheng AC, Peacock SJ, Prescott HC. Pathophysiology, transmission, diagnosis, and treatment of coronavirus disease 2019 (COVID-19): A review. JAMA 2020;324:782-93.

3. Hu B, Guo H, Zhou P, Shi ZL. Characteristics of SARS-CoV-2 and COVID-19. Nat Rev Microbiol 2021;19:141-54.

4. Murray JF. The structure and function of the lung. Int J Tuberc Lung Dis 2010;14:391-6.

5. Nguyen HL, Thai NQ, Truong DT, Li MS. Remdesivir strongly binds to both RNA-dependent RNA polymerase and main protease of SARS-CoV-2: Evidence from Molecular Simulations.. J Phys Chem B 2020;124:11337-48.

6. Brewster CT, Choong J, Thomas C, Wilson D, Moiemen N. Steam inhalation and paediatric burns during the COVID-19 pandemic. Lancet 2020;395:1690.

7. Farnsworth NR, Akerele O, Bingel AS, Soejarto DD, Guo Z. Medicinal plants in therapy. Bull World Health Organ 1985;63:965-81.

8. Guasch L, Sala E, Ojeda MJ, Valls C, Bladé C, Mulero M, et al. Identification of novel human dipeptidyl peptidase-IV inhibitors of natural origin (Part II): In silico prediction in antidiabetic extracts. PLoS One 2012;7:e44972.

9. Slikkerveer LJ. The challenge of non-experimental validation of mac plants: Towards a multivariate model of transcultural utilization of medicinal, aromatic and cosmetic plants. Frontis. 2006;17:309.

10. Hostettmann, K, Marston A. Twenty years of research into medicinal plants: Results and perspectives. Phytochem Rev 2002;1:275-85.

11. Pitt JJ. Principles and applications of liquid chromatographymass spectrometry in clinical biochemistry. Clin Biochem Rev 2009;30:19-34

12. Hostettmann KM, Marston A, Ndjoko K, Wolfender JL. The potential of African plants as a source of drugs. Curr Org Chem 2000;4:9731010 .

13. Cos P, Maes L, Berghe DV, Hermans N, Pieters L, et al. Plant substances as anti-HIV agents selected according to their putative mechanism of action. J Nat Prod 2004;67:284-93.

14. Sala E, Guasch L, Iwaszkiewicz J, Mulero M, Salvado MJ, et al. Identification of human IKK-2 inhibitors of natural origin (Part II): In silico prediction of IKK-2 inhibitors in natural extracts with known anti-inflammatory activity. Eur J Med Chem 2011;46:6098-103.

15. Cragg GA, Newman DJ. Biodiversity: A continuing source of novel drug leads. Pure Appl Chem 2005;77:7-24.

16. Altemimi A, Lakhssassi N, Baharlouei A, Watson DG, Lightfoot DA. Phytochemicals: Extraction, isolation, and identification of bioactive compounds from plant extracts. Plants (Basel) 2017;6:42.

17. Zhang M, Zhao R, Wang D, Wang L, Zhang Q, Wei S, et al. Ginger (Zingiber officinale Rosc.) and its bioactive components are potential resources for health beneficial agents. Phytother Res 2021;35:711-42.

18. Meghwal M, Goswami TK. Piper nigrum and piperine: An update. Phytother Res 2013;27:1121-30.

19. Cortés-Rojas DF, de Souza CR, Oliveira WP. Clove (Syzygium aromaticum): A precious spice Asian Pac J Trop Biomed 2014;4:90-6.

20. Reddy BS, Rao NR, Vijeepallam K, Pandy V. Phytochemical, pharmacological and biological profiles of Tragia Species (Family: Euphorbiaceae). Afr J Tradit Complement Altern Med 2017;14:105-12.

21. Jawhari FZ, El Moussaoui A, Bourhia M, Imtara H, Mechchate H, Es-Safi I, et al. Anacyclus pyrethrum (L): Chemical composition, analgesic, anti-inflammatory, and wound healing properties. Molecules 2020;25:5469.

22. Hossain MS, Urbi Z, Sule A, Rahman KM. Andrographis paniculata (Burm. f.) Wall. ex Nees: A review of ethnobotany, phytochemistry, and pharmacology. Sci World J 2014;2014:274905.

23. Vijayakumar M, Govindarajan R, Rao GM, Rao CV, Shirwaikar A, Mehrotra S, et al. Action of Hygrophila auriculata against streptozotocininduced oxidative stress. J Ethnopharmacol 2006;104:356-61.

24. Bag A, Bhattacharyya SK, Chattopadhyay RR. The development of Terminalia chebula Retz. (Combretaceae) in clinical research. Asian Pac J Trop Biomed 2013;3:244-52.

25. Bose D, Chatterjee S. Antibacterial activity of green synthesized silver nanoparticles using Vasaka (Justicia adhatoda L.) Leaf extract. Indian J Microbiol 2015;55:163-7.

26. Arumugam G, Swamy MK, Sinniah UR. Plectranthus amboinicus (Lour.) Spreng: Botanical, phytochemical, pharmacological and nutritional significance. Molecules 2016;21:369.

27. El-Far AH, Shaheen HM, Alsenosy AW, El-Sayed YS, Jaouni SK, 
Mousa SA. Costus speciosus: Traditional uses, phytochemistry, and therapeutic potentials. Phoogn Rev 2018;12:120-7.

28. Saha S, Ghosh S. Tinospora cordifolia: One plant, many roles. Anc Sci Life 2012;31:151-9.

29. Patel JJ, Acharya SR, Acharya NS. Clerodendrum serratum (L.) Moon. A review on traditional uses, phytochemistry and pharmacological activities. J Ethnopharmacol 2014;154:268-85.

30. Dinda B, Das N, Dinda S, Dinda M, Sarma IS. The genus Sida L. a traditional medicine: Its ethnopharmacological, phytochemical and pharmacological data for commercial exploitation in herbal drugs industry. J Ethnopharmacol 2015;176:135-76

31. Pirzada AM, Ali HH, Naeem M, Latif M, Bukhari AH, Tanveer A. Cyperus rotundus L.: Traditional uses, phytochemistry, and pharmacological activities. J Ethnopharmacol 2015;174:540-60

32. Kaushik S, Jangra G, Kundu V, Yadav JP, Kaushik S. Anti-viral activity of Zingiber officinale (Ginger) ingredients against the Chikungunya virus. Virus Dis 2020;31:1-7.

33. Chang JS, Wang KC, Yeh CF, Shieh DE, Chiang LC. Fresh ginger (Zingiber officinale) has anti-viral activity against human respiratory syncytial virus in human respiratory tract cell lines. J Ethnopharmacol 2013;145:146-51.

34. Haridas M, Sasidhar V, Nath P, Abhithaj J, Sabu A, Rammanohar P. Compounds of Citrus medica and Zingiber officinale for COVID-19 inhibition: In silico evidence for cues from Ayurveda. Futur J Pharm Sci 2021;7:13.

35. Pandey P, Singhal D, Khan F, Arif M. An in silico screening on Piper nigrum, Syzygium aromaticum and Zingiber officinale roscoe derived compounds against SARS-CoV-2: A drug repurposing approach. Bioint Res Appl Chem 2021;11:11122-34.

36. Umashankar V, Deshpande SH, Hegde HV, Singh I, Chattopadhyay D. Phytochemical moieties from Indian traditional medicine for targeting dual hotspots on SARS-CoV-2 spike protein: An integrative in-silico approach. Front Med (Lausanne) 2021;8:672629.

37. Sangiamsuntorn K, Suksatu A, Pewkliang Y, Thongsri P, Kanjanasirirat P, Manopwisedjaroen S, et al. Anti-SARS-CoV-2 activity of Andrographis paniculata extract and its major component andrographolide in human lung epithelial cells and cytotoxicity evaluation in major organ cell representatives bioRxiv 2020;2020:415836.

38. Enmozhi SK, Raja K, Sebastine I, Joseph J. Andrographolide as a potential inhibitor of SARS-CoV-2 main protease: An in silico approach. J Biomol Struct Dyn 2021;39:3092-8.

39. Vincent S, Arokiyaraj S, Saravanan M, Dhanraj M. Molecular docking studies on the anti-viral effects of compounds from Kabasura Kudineer on SARS-CoV-2 3CL ${ }^{\text {pro }}$. Front Mol Biosci 2020;7:613401.

40. Prasad A, Muthamilarasan M, Prasad M. Synergistic antiviral effects against SARS-CoV-2 by plant-based molecules. Plant Cell Rep 2020;39:1109-14.

41. Ghosh R, Chakraborty A, Biswas A, Chowdhuri S. Identification of alkaloids from Justicia adhatoda as potent SARS CoV-2 main protease inhibitors: An in silico perspective. J Mol Struct 2021;1229:129489.

42. Bag A, Bag A. Treatment of COVID-19 patients: Justicia adhatoda leaves extract is a strong remedy for COVID-19 Case report analysis and docking based study. ChemRxiv 2020;2020:604.

43. Pandey AT, Pandey I, Zamboni P, Gemmati D, Kanase A, Singh AV, et al. Traditional herbal remedies with a multifunctional therapeutic approach as an implication in COVID-19 associated Co-infections. Coatings 2020;10:761

44. Maste MM, Saxena A. Screening of Plectranthus amboinicus against COVID-19 in silico approach. J Appl Pharm Sci 2020;10:90-7.

45. Saif-Al-Islam M. Saussurea costus may help in the treatment of COVID-19. Sohag Med J 2020;24:6-17.

46. Jena S, Munusami P, Mm B, Chanda K. Computationally approached inhibition potential of Tinospora cordifolia towards COVID-19 targets. Virus Dis 2021;32:65-77.

47. Chowdhury P. In silico investigation of phytoconstituents from Indian medicinal herb Tinospora cordifolia (Giloy) against SARS-CoV-2 (COVID-19) by molecular dynamics approach. J Biomol Struct Dyn 2020;2020:1-18.

48. Shree P, Mishra P, Selvaraj C, Singh SK, Chaube R, Garg N, et al. Targeting COVID-19 (SARS-CoV-2) main protease through active phytochemicals of ayurvedic medicinal plants Withania somnifera (Ashwagandha), Tinospora cordifolia (Giloy) and Ocimum sanctum (Tulsi) a molecular docking study. J Biomol Struct Dyn 2020;27:1-14.

49. Thakkar SS, Shelat F, Thakor P. Magical bullets from an indigenous Indian medicinal plant Tinospora cordifolia: An in silico approach for the antidote of SARS-CoV-2 Egypt J Petroleum 2021;30:53-66.

50. Balkrishna A, Khandrika L, Varshney A. Giloy Ghanvati (Tinospora cordifolia (Willd.) Hook. f. and Thomson) reversed SARS-CoV-2 viral spike-protein induced disease phenotype in the xenotransplant model of humanized Zebrafish. Front Pharmacol 2021;12:635510.

51. Sulaiman CT, Deepak M, Ramesh PR, Mahesh K, Anandan EM, Balachandran I. Chemical profiling of selected Ayurveda formulations recommended for COVID-19. Beni Suef Univ J Basic Appl Sci 2021;10:2

52. Mahrosh HS, Mustafa G. An in silico approach to target RNAdependent RNA polymerase of COVID-19 with naturally occurring phytochemicals. Environ Dev Sustain 2021;3:1-14

53. Silva JK, Figueiredo PL, Byler KG, Setzer WN. Essential oils as antiviral agents. potential of essential oils to treat SARS-CoV-2 infection: An in-silico investigation. Int J Mol Sci 2020;21:3426.

54. David A, Wang F, Sun X, Li H, Lin J, Li P, et al. Chemical composition, antioxidant, and antimicrobial activities of Vetiveria zizanioides $(\mathrm{L}$. Nash essential oil extracted by carbon dioxide expanded ethanol. Molecules 2019;24:1897

55. Adhikari B, Marasini BP, Rayamajhee B, Bhattarai BR, Lamichhane G, Khadayat $\mathrm{K}$, et al. Potential roles of medicinal plants for the treatment of viral diseases focusing on COVID-19: A review. Phytother Res 2021;35:1298-312

56. Jain R, Sharma A, Gupta S, Sarethy IP, Gabrani R. Solanum nigrum: Current perspectives on therapeutic properties. Altern Med Rev 2011;16:78-85

57. Jain J, Kumar A, Narayanan V, Ramaswamy RS, Sathiyarajeswaran P, Shree Devi MS, et al. Antiviral activity of ethanolic extract of Nilavembu Kudineer against dengue and chikungunya virus through in vitro evaluation. J Ayurveda Integr Med 2020;11:329-35.

58. Srivastava A, Rengaraju M, Srivastava S, Narayan V, Gupta V, Upadhayay R. A double blinded placebo controlled comparative clinical trial to evaluate the effectiveness of Siddha medicines, Kaba Sura Kudineer (KSK) and Nilavembu Kudineer (NVK) along with standard Allopathy treatment in the management of symptomatic COVID 19 patients a structured summary of a study protocol for a randomized controlled trial. Trials 2021;22:130.

59. Shafreen RM, Priya A, Shunmugiah KP. Ethnomedicines of Indian origin for combating COVID-19 infection by hampering the viral replication: Using structure-based drug discovery approach. J Biomol Struct Dyn 2020;23:1-16

60. Kiran G, Karthik L, Shree Devi MS, Sathiyarajeswaran P, Kanakavalli K, Kumar KM, et al. In silico computational screening of Kabasura Kudineer official siddha formulation and JACOM against SARS-CoV-2 spike protein. J Ayurveda Integr Med 2020;25:30024-3.

61. Kadiyala M, Ponnusankar S, Elango K. Calotropis gigantiea (L.) R. $\mathrm{Br}$ (Apocynaceae): A phytochemical and pharmacological review. J Ethnopharmacol 2013;150:32-50.

62. Rahman S, Parvin R. Therapeutic potential of Aegle marmelos (L.) an overview. Asian Pac J Trop Dis 2014;4:71-7.

63. Ayyanar M, Subash-Babu P. Syzygium cumini (L.) Skeels: A review of its phytochemical constituents and traditional uses. Asian Pac J Trop Biomed 2012;23:240-6.

64. Alzohairy MA. Therapeutics role of Azadirachta indica (Neem) and their active constituents in diseases prevention and treatment. Evid Based Complement Alternat Med 2016;2016:7382506.

65. Shendge PN, Belemkar S. Therapeutic potential of Luffa acutangula: A review on its traditional uses, phytochemistry, pharmacology and toxicological aspects. Front Pharmacol 2018;9:1177.

66. Ahmad A, Husain A, Mujeeb M, Khan SA, Najmi AK, Siddique NA, et al. A review on therapeutic potential of Nigella sativa: A miracle herb. Asian Pac J Trop Biomed 2013;3:337-52.

67. Rao PV, Gan SH. Cinnamon: A multifaceted medicinal plant. Evid Based Complement Alternat Med 2014;2014:642942.

68. Hewlings SJ, Kalman DS. Curcumin: A review of its effects on human health. Foods 2017;6:92

69. Salehi B, Zakaria ZA, Gyawali R, Ibrahim SA, Rajkovic J, Shinwari ZK, et al. Piper species: A comprehensive review on their phytochemistry, biological activities and applications. Molecules 2019;24:1364.

70. Chen W, Vermaak I, Viljoen A. Camphor--a fumigant during the black death and a coveted fragrant wood in ancient Egypt and Babylon--a review. Molecules 2013;18:5434-54.

71. Ruan J, Zou J, Cai Y. Studies on chemical constituents of Smilax china. Zhong Yao Cai 2005;28:24-6.

72. Zahidin NS, Saidin S, Zulkifli RM, Muhamad II, Ya'akob H, Nur H. A review of Acalypha indica L. (Euphorbiaceae) as traditional medicinal plant and its therapeutic potential. J Ethnopharmacol 2017;207:146-73.

73. Yadav V, Krishnan A, Vohora D. A systematic review on Piper longum L.: Bridging traditional knowledge and pharmacological evidence for 
future translational research. J Ethnopharmacol 2020;247:112255.

74. Abourashed EA, El-Alfy AT. Chemical diversity and pharmacological significance of the secondary metabolites of nutmeg (Myristica fragrans Houtt.). Phytochem Rev 2016;15:1035-56.

75. Kaur N, Kaur B, Sirhindi G. Phytochemistry and pharmacology of Phyllanthus niruri L.: A review. Phytother Res 2017;31:980-1004.

76. Jahan R, Al-Nahain A, Majumder S, Rahmatullah M. Ethnopharmacological significance of Eclipta alba (L.) Hassk. (Asteraceae). Int Sch Res Notices 2014;2014:385969.

77. Patel DK, Laloo D, Kumar R, Hemalatha S. Pedalium murex Linn.: An overview of its phytopharmacological aspects. Asian Pac J Trop Med 2011;4:748-55.

78. Gürbüz N, Uluişik S, Frary A, Frary A, Doğanlar S. Health benefits and bioactive compounds of eggplant. Food Chem 2018;268:602-10.

79. Parhira S, Yang ZF, Zhu GY, Chen QL, Zhou BX, Wang YT, et al. In vitro anti-influenza virus activities of a new Lignan glycoside from the latex of Calotropis gigantea. PLoS One 2014;9:e104544.

80. Maity P, Hansda D, Bandyopadhayay U, Mishra DK. Biological activities of crude extracts of chemical constituents of Bael, Aegle marmelos (L.) Corr. Indian J Exp Biol 2009;47:849-61.

81. Sood R, Swarup D, Bhatia S, Kulkarni DD, Dey S, Saini M, et al. Antiviral activity of crude extracts of Eugenia jambolana Lam. against highly pathogenic avian influenza (H5N1) virus. Indian J Exp Biol 2012;50:179-86

82. Ahmad A, Javed MR, Rao AQ, Husnain T. Designing and screening of universal drug from neem (Azadirachta indica) and standard drug chemicals against influenza virus nucleoprotein. BMC Complement Altern Med 2016;16:519.

83. Tiwari V, Darmani NA, Yue BY, Shukla D. In vitro antiviral activities of neem (Azardirachta indica L.) bark extract against herpes simplex virus Type-1 infection. Phytother Res 2010;24:1132-40.

84. Bharitkar YP, Bathini S, Ojha D, Ghosh S, Mukherjee H, Kuotsu $\mathrm{K}$, et al. Antibacterial and antiviral evaluation of sulfonoquinovosyldiacylglyceride: A glycolipid isolated from Azadirachta indica leaves. Lett Appl Microbiol 2014;58:184-9.

85. Borkotoky S, Banerjee M. A computational prediction of SARS-CoV-2 structural protein inhibitors from Azadirachta indica (Neem). J Biomol Struct Dyn 2021;39:4111-21.

86. Baildya N, Khan AA, Ghosh NN, Dutta T, Chattopadhyay AP. Screening of potential drug from Azadirachta indica (Neem) extracts for SARSCoV-2: An insight from molecular docking and MD-simulation studies.
J Mol Struct 2021;1227:129390.

87. Umar S, Munir M, Subhan S, Azam T, Nisa QU, Khan MI, et al. Protective and antiviral activities of Nigella sativa against avian influenza (H9N2) in turkeys Nigella sativa. J Saudi Soc Agric Sci 2016;2016:1-4.

88. Zandia K, Ramedania E, Mohammadic K, Tajbakhshd S, Deilamia I, Rastiana Z, et al. Evaluation of antiviral activities of curcumin derivatives against HSV-1 in Vero cell line. Nat Prod Commun 2010;5:1935-8.

89. Kim HJ, Yoo HS, Kim JC, Park CS, Choi MS, Kim M, et al. Antiviral effect of Curcuma longa Linn extract against hepatitis B virus replication. J Ethnopharmacol 2009;124:189-96.

90. Jiang ZY, Liu WF, Zhang XM, Luo J, Ma YB, Chen JJ. Anti-HBV active constituents from Piper longum. Bioorg Med Chem Lett 2013;23:2123-7.

91. Mair CE, Liu R, Atanasov AG, Schmidtke M, Dirsch VM, Rollinger JM. Antiviral and anti-proliferative in vitro activities of piper amides from black pepper. Plant Med 2016;82:S1-381

92. Wang WX, Qian JY, Wang XJ, Jiang AP, Jia AQ. Anti-HIV-1 activities of extracts and phenolics from Smilax china L. Pak J Pharm Sci 2014;27:147-51.

93. Tan WC, Jaganath IB, Manikam R, Sekaran SD. Evaluation of antiviral activities of four local Malaysian Phyllanthus species against herpes simplex viruses and possible antiviral target. Int J Med Sci 2013;10:1817-29.

94. Wahyuni T, Azmi D, Permanasari A, Adianti M, Tumewu L, Widiandani A, et al. Anti-viral activity of Phyllanthus niruri against hepatitis C virus. Malay Appl Biol 2019;48:105-11.

95. Faral-Tello P, Mirazo S, Dutra C, Pérez A, Geis-Asteggiante L, Frabasile S, et al. Cytotoxic, virucidal, and antiviral activity of South American plant and algae extracts. Sci World J 2012;2012:174837.

96. Lee SH, Tang YQ, Rathkrishnan A, Wang SM, Ong KC, Manikam R, et al. Effects of cocktail of four local Malaysian medicinal plants (Phyllanthus spp.) against dengue virus 2. BMC Complement Altern Med 2013;26;13:192.

97. Manvar D, Mishra M, Kumar S, Pandey VN. Identification and evaluation of anti-hepatitis C virus phytochemicals from Eclipta alba. J Ethnopharmacol 2012;144:545-54

98. Di Sotto A, Di Giacomo S, Amatore D, Locatelli M, Vitalone A, Toniolo C, et al. A polyphenol rich extract from Solanum melongena L. DR2 peel exhibits antioxidant properties and anti-herpes simplex virus Type 1 activity in vitro. Molecules 2018;23:2066 